\begin{tabular}{|l|l|l||}
\hline \multicolumn{2}{|c|}{ PublisherInfo } \\
\hline \hline PublisherName & $:$ & BioMed Central \\
\hline \hline PublisherLocation & $:$ & London \\
\hline \hline PublisherImprintName & $:$ & BioMed Central \\
\hline \hline
\end{tabular}

\title{
Silencing in mice
}

\begin{tabular}{|l|l|l||}
\hline \multicolumn{2}{|c|}{ ArticleInfo } \\
\hline \hline ArticleID & $:$ & 4550 \\
\hline \hline ArticleDOI & $:$ & $10.1186 /$ gb-spotlight-20020808-01 \\
\hline \hline ArticleCitationID & $:$ & spotlight-20020808-01 \\
\hline \hline ArticleSequenceNumber & $:$ & 216 \\
\hline \hline ArticleCategory & $:$ & Research news \\
\hline ArticleFirstPage & $:$ & 1 \\
\hline \hline ArticleLastPage & $:$ & 2 \\
\hline \hline & & RegistrationDate : 2002-8-8 \\
\hline ArticleHistory & $:$ & OnlineDate \\
\hline \hline ArticleCopyright & $:$ & BioMed Central Ltd2002-8-8 \\
\hline \hline ArticleGrants & $:$ & \\
\hline \hline ArticleContext & $:$ & 130593311 \\
\hline \hline
\end{tabular}




\section{Jonathan B Weitzman}

Email: jonathanweitzman@hotmail.com

In an Advanced Online Publication in Nature Genetics, Lewis et al. describe a simple technique for silencing gene expression in postnatal mice using RNA interference (RNAi) (Nature Genetics 29 July 2002, doi:10.1038/ng944). The authors exploited a 'high-pressure delivery' technique to deliver siRNA (short interfering RNA) to the organs of postnatal mice. They injected plasmid solutions into the tail vein and monitored expression of co-injected constructs encoding a firefly luciferase reporter gene. They achieved up to $90 \%$ inhibition levels in the liver, spleen, kidney, lung and pancreas. Inhibition of gene expression in the liver was dose-dependent - as little as $0.05 \mu \mathrm{g}$ siRNA caused a $36 \%$ reduction in luciferase gene expression. Lewis et al.also show that injecting siRNA could effectively inhibit transgene expression.

\section{References}

1. Nature Genetics, [http://www.nature.com/ng]

2. Potent and specific genetic interference by double-stranded RNA in Caenorhabditis elegans. 